\title{
A Review on Integration of Balanced Scorecard and Intellectual Capital for Performance Evaluation of Banks: A New Measurement Framework
}

\author{
LEENA AFROZ MOSTOFA CHOWDHURY*
}

\begin{abstract}
In this age of innovation and globalization, interest in research on measuring and analyzing intellectual capital (IC) and determining its impact on business performance is on the rise. This study is intended to review the literature concerning the effects of implementing the Balance Scorecard (BSC) on the organizational performance of banks, with the Intellectual Capital (IC) enhancement being the mediator. Based on the literature a new comprehensive performance measurement framework for banks has been proposed. This framework can be validated through further research by integrating the interaction between BSC and IC components in the context of Bangladeshi banks by examining different banking environment i.e. nationalized, private commercial, foreign commercial and Islamic banks, as the literature shows strong deviation in measurement models depending on the nature of business.
\end{abstract}

Keywords: Balanced Scorecard, Intellectual capital, Organizational performance.

\section{INTRODUCTION}

The operating performance of banks is highly reliant on sustainable client relationships that are subject to the caliber of human resource and banks' ability to keep their clients satisfied. The shortcomings of conventional financial reporting system have provoked an evolving dialogue on modeling, measuring and reporting a bank's intangible assets i.e. intellectual capital (IC) for sustainable performance growth (Arora, 2002) strategically linked with the overall mission and vision of the firm through implementation of Balanced Scorecard (BSC) (Kaplan and Norton, 1992). This study primarily aims to contribute to the relatively scarce empirical literature emphasizing on the integration effects of IC and BSC on business performance in the banking

\footnotetext{
* Lecturer, Department of Business Administration, University of Asia Pacific, Dhaka. E-mail: leena_du10@hotmail.com.
} 
industry and to find out the relevance of these two techniques in measuring performance individually and collectively in the financial sector.

\section{BALANCEDSCORECARDAS PERFORMANCEMEASUTREMENT TECHNIQUEIN BANKS}

Poor strategic implementation through reliance on traditional financial ratios to review the banking performance motivated Kaplan and Norton (1992) to recommend the Balanced Scorecard as an instrument to associate performance measures from four different standpoints: Financial, Customer, Internal Processes, and Learning and Growth. BSC aligns the value of intangible assets with tangible ones including financial and non-financial criteria in a single report and in a "balanced" way (Kaplan and Norton, 2004). Garrison and Noreen (2000) have indicated that learning is necessary to improve internal business process, resulting in customer satisfaction and enhancement in the financial results. Zhang and $\mathrm{Li}$ (2009) found BSC to raise the value of performance evaluation system in commercial banks in China. Ahmed et al. (2011) through a sample of 27 Pakistani banks and Fakhri et al. (2011) through an extensive literature review and a survey with a sample of 55 banks in Libya, reported that many of the banks tended to implement customer related measures and other non financial measures such as learning and employee growth. Dave (2012), Panicker and Seshadri (2013), Nijjar and Kalaf (2012). Elif Öztürk1 \& Ali Coskun (2014) reviewed strategic approach for BSC in banks and concluded that preparation of the balanced scorecard for the banks is more functional than reporting financial performance only. The issue of the key performance indicators (KPIs) for the four perspectives for banks and other financial institutions has been center of research interest among several scholars. The following table summarizes the major indicators:

FIGURE 1: KPIs for BSC Implementation

\begin{tabular}{|c|c|c|}
\hline BSC Perspective & KPIS & Research Authors \\
\hline $\begin{array}{l}\text { Financial } \\
\text { perspective }\end{array}$ & $\begin{array}{l}\text { Capital Adequacy Ratio, Cash- Deposit } \\
\text { Ratio, Credit Deposit Ratio, Net Interest } \\
\text { Margin to Total Asset Ratio, Interest } \\
\text { Income to Total Asset Ratio, Investment } \\
\text { Deposit Ratio, Operating income, } \\
\text { Return on Investment (ROI), Revenue } \\
\text { Growth, Return on Asset (ROA), } \\
\text { Return on Equity(ROE), Net Profit after } \\
\text { tax, Earnings per Share (EPS), } \\
\text { Economic Value Added (EVA), 30-day } \\
\text { loan delinquencies, Net Profit Margin }\end{array}$ & $\begin{array}{l}\text { Evans, (2004); Banker } \\
\text { et al, (2004); Lipe \& } \\
\text { Salterio 2000 (2002); } \\
\text { Lu-Ann Bean and Bill } \\
\text { D. Jarnagin (2002); } \\
\text { Wu, Tzeng and Chen, } \\
\text { (2009); Dave et al, } \\
(2012) \text {. }\end{array}$ \\
\hline
\end{tabular}




\begin{tabular}{|c|c|c|}
\hline BSC Perspective & KPIS & Research Authors \\
\hline $\begin{array}{l}\text { Customer } \\
\text { perspective }\end{array}$ & $\begin{array}{l}\text { Customer Satisfaction Survey, } \\
\text { Customer Retention, New customer } \\
\text { acquisition, Customer response time, } \\
\text { Market share, Post-sales service and } \\
\text { Customer profitability, Profit per } \\
\text { customer }\end{array}$ & $\begin{array}{l}\text { Kaplan and Norton, } \\
\text { (1996a); Kaplan \& } \\
\text { Atkinson, (1998); } \\
\text { Evans, (2004); Hoque } \\
\text { et.al, (1997 and } \\
\text { 2003); Banker } \text { et al., } \\
\text { (2004); Zimmerman, } \\
\text { (2003); Malina and } \\
\text { Selto, (2001); Wu, } \\
\text { Tzeng and Chen, } \\
\text { (2009). }\end{array}$ \\
\hline $\begin{array}{l}\text { Internal business } \\
\text { process } \\
\text { perspective }\end{array}$ & $\begin{array}{l}\text { Business per employee, Profit per } \\
\text { employee, Wage bill to Income Ratio, } \\
\text { Product/process design, Product } \\
\text { development, Service efficiency, } \\
\text { effectiveness and quality, No. of new } \\
\text { service items, customer complaints, } \\
\text { Transaction efficiency, Rationalized } \\
\text { forms \& processes, Management } \\
\text { performance, Sales performance }\end{array}$ & $\begin{array}{l}\text { Wu, Tzeng and Chen, } \\
\text { (2009); Dave et al, } \\
\text { (2012). }\end{array}$ \\
\hline $\begin{array}{l}\text { Learning and } \\
\text { growth } \\
\text { perspective }\end{array}$ & $\begin{array}{l}\text { Employee training, Individual and } \\
\text { corporate self-improvement, } \\
\text { Investments in new technology, } \\
\text { Innovative products \& services, } \\
\text { Creativity and innovation, } \\
\text { Empowerment, Employee development, } \\
\text { Customer orientation, Job satisfaction, } \\
\text { Intellectual abilities of employees, } \\
\text { Information systems, and } \\
\text { Organizational procedures to manage a } \\
\text { business, Adaptation ability to changes, } \\
\text { Responses of customer service, } \\
\text { Professional training, Employee } \\
\text { stability, Employee satisfaction, } \\
\text { Organization competence }\end{array}$ & $\begin{array}{l}\text { Zimmerman, (2001); } \\
\text { Kaplan \& Norton, } \\
\text { (1996a); Evans, 2004; } \\
\text { Schneider, (1993); } \\
\text { Usala, (1996); } \\
\text { Istiaque et al, (2007); } \\
\text { M. Lebas, (1995); } \\
\text { Wu, Tzeng and Chen, } \\
\text { (2009). }\end{array}$ \\
\hline
\end{tabular}




\section{INTELLECTUAL CAPITAL AND ORGANIZATIONAL PERFORMANCE}

The term "Intellectual capital" was originally introduced by John Kenneth Galbraith in 1969 as an intellectual contribution owned by individuals (Feiwal, (1975) and Ding, (2010)). Stewart (1997) in his definition for IC included education, knowledge, information, expertise, intellectual property in addition to experiences that are used to create wealth. Edvinsson and Malone (1997), Sveiby (1997), Roos et al.(1997), Bontis (1999), O’Donnell et al. (2004, 2006), Sallebrant et al. (2007), Curado and Bontis (2007) among others, argued that intellectual capital should have the following characteristics:

(i) Intangibility;

(ii) Knowledge that creates value and;

(iii) Effect of collective practice.

According to Edvinsson \& Malone (1997) IC is the sum of human and structural capital. They further categorized structural capital into organizational capital and customer capital. Stewart (1997) approved Edvinsson and Malone's classification to some extent. However he separated customer capital from the structural one and gave it equal importance. Competitive capital (Rothberg and Erickson, 2002), innovation capital (Tseng and Goo, 2005; Wang and Chang, 2005), Social capital (Inkpen and Tsang, 2005; Nahapiet and Ghoshal, 1998; Davies and Magowan, 2002) and technological capital (Bueno et al., 2006) have been proposed as a fourth intellectual capital element. Bontis (1996) advocated for relationship capital as a broader idea that encompasses customer capital as well as all the significant associations, such as company-customer relations, company-supplier relations, employee-supervisor relations, inter-employee relations, inter-departmental relations, among other internal social capital-based interaction (Leana and Van Buren, 1999; Nahapiet and Ghoshal, 1998). Adler and Kwon (2002) and Chang (2010) agree that Bontis' definition for relationship capital shares the similar elements with social capital. Despite the fact that intellectual literature still debates on the components of Intellectual Capital, IC is essentially a multidimensional idea with the amalgamation of the following elements of the firm (Bontis, 1996; Bontis, 1998; Johnson, 1999; Chen 2001; Meritum Project, 2002; Cabrita and Vaz, 2006): 
FIGURE 2: Components of IC (Johnson, 1999)

A. Human capital (HC): The idea capital (the manpower for knowledge-based duties and employee aptitudes and attitudes) and leadership capital (the qualities of a manager)

B. Structural capital (SC): The innovation capital (patents, trademarks, copyright and knowledge archives) cultural capital (organizational internal relations) and process capital (work procedures and trade secrets)

C. Relational capital (RC): Firm's relationships with customers, suppliers and online-community members

Nevertheless extensive research on IC initiated in the knowledge intensive developed countries, this experience has universal appeal as evidenced in researches within Australia (Bontis and Girardi, 2000), Malaysia (Bontis et al., 2000), Ireland (O'Regan et al., 2001; 2005), Mexico (Trevinyo-Rodriguez and Bontis, 2007), Portugal (Cabrita et al., 2007; Cabrita and Bontis, 2008), Germany (Kristandl and Bontis, 2007), Egypt (Seleimet al., 2004, 2007), Serbia (Bontis, Janosević, Dzenopoljac 2013), Belgium and Luxemberg (Mention and Bontis, 2013) and others.

\section{IMPACT OF INTELLECTUAL CAPITAL ON BANKING PERFORFORMANCE}

Banks meet the requirements of knowledge-intensive organizations as most of their actions are of an intellectual nature with well educated, competent and continuously trained employees forming the majority of the workforce (Alvesson, 2000). Banking industry, in particular, represents ample opportunities for research setting as banking operations rely on the amalgamation of information and communication technologies (ICTs) for the development of new and innovative products and services and close interaction with customers through human resource and are highly regulated, diverse, risky by nature and market sensitive (Bontis, 2013). 
FIGURE 3: Summary of Researches on Influence of IC Performance on Banking Performance

\begin{tabular}{c|c|}
\hline Author(s) & \multicolumn{1}{c|}{ Research Origin } \\
\hline Mavridis (2004) & $\begin{array}{l}\text { 141 Japanese banks for the } \\
\text { period 2001-2003 }\end{array}$
\end{tabular}

Mavridis and

Kyrmizoglou, (2005)

Mohiuddin et al.

(2006)

Cabrita and Bontis (2008)

Young et al., (2009)

Puntillo (2009)
17 Greek banks for the period 1996-1999

17 Bangladeshi commercial banks for the period from 2002 to 2004

53 Portuguese banks
Major Findings

In terms of corporate performance, best performing banks mainly have very good results in their use of IC and less so in their use of physical capital.

Corporate performance of these banks is significantly affected by IC (mainly human capital).

Human capital is the most dominant factor in IC measurement through VAIC.

Human Capital has important effects on both structural capital and relational capital and influences relational capital not only directly but also indirectly through the structural capital and influences business performance indirectly.

8 Asian economies (Hong Kong, Indonesia, Malaysia, the Philippines, Singapore, South Korea, Thailand, and Taiwan) over the 6 year period (1996-2001)

Italian banks
Human capital and physical capital were the main driving forces of value creation in the observed period.

The study found a positive relationship only between capital employed efficiency (CEE) and return on assets (ROA) and return on equity (ROE) 


\begin{tabular}{|c|c|c|}
\hline Author(s) & Research Origin & Major Findings \\
\hline Joshi et al., (2010) & $\begin{array}{l}11 \text { Australian banks for the } \\
\text { period 2005-2007 using } \\
\text { VAIC methodology }\end{array}$ & $\begin{array}{l}\text { The value creation capability } \\
\text { of banks in Australia is } \\
\text { directly attributable to their } \\
\text { Human Capital Employed. }\end{array}$ \\
\hline $\begin{array}{l}\text { Abdulsalam et al., } \\
\text { (2011) }\end{array}$ & $\begin{array}{l}\text { Kuwaiti banks (For the } \\
\text { period 1996-2006) }\end{array}$ & $\begin{array}{l}\text { Commercial banks } \\
\text { outperformed non- } \\
\text { commercial ones over } 3 \text { years } \\
\begin{array}{l}\text { (2004-2006) showing better } \\
\text { exploitation of IC and } \\
\text { physical capital. }\end{array}\end{array}$ \\
\hline $\begin{array}{l}\text { Bontis, Janosevic and } \\
\text { Dzenopoljac (2013) }\end{array}$ & $\begin{array}{l}\text { Serbian banks through } \\
\text { VAIC performance }\end{array}$ & $\begin{array}{l}\text { Physical capital dominates } \\
\text { profitability and ROE but its } \\
\text { role must be replaced by } \\
\text { impacts of HCE and SCE if } \\
\text { banks are to sustain } \\
\text { competitive advantage in the } \\
\text { long run. Human capital is } \\
\text { undervalued and not } \\
\text { exploited properly. Structural } \\
\text { capital, resulting from the } \\
\text { external relations of banks } \\
\text { (mostly owned by foreign } \\
\text { entities), has an inadequate } \\
\text { effect on corporate } \\
\text { performance. }\end{array}$ \\
\hline $\begin{array}{l}\text { Mention and Bontis } \\
\text { (2013) }\end{array}$ & $\begin{array}{l}200 \text { banks within } \\
\text { Luxembourg and Belgium }\end{array}$ & $\begin{array}{l}\text { Human capital was both a } \\
\text { direct and an indirect } \\
\text { contributor to business } \\
\text { performance. Structural and } \\
\text { relational capitals were found } \\
\text { to be positively related to } \\
\text { business performance. }\end{array}$ \\
\hline
\end{tabular}

The studies on Malaysian banks (Goh, 2005) and (Ting and Lean, 2009), Indian banks (Kamath, 2007), Japanese banks (Mavridis, 2004) and Pakistani banks (Kamath (2010) and Shaari et al., (2011)) indicate that the leading banks are those who primarily perform best in terms of usage of their IC. Interesting observation of these studies was that the inter component relationship between IC was determined by the nature and portfolio of the banking business of the country. The research on Portuguese banks by Cabrita and Bontis (2008) and on 
US banks, by Reed et al. (2006) found that HC through RC and SC to positively affect financial performance in retail based banks. Comparing service and nonservice industries in Malaysia, Bontis et al. (2000) indicated that $\mathrm{HC}$ is positively related to customer capital in both settings. Mention and Bontis (2013) found HC to be the exclusive direct positive and statistically significant contributor to business performance in Belgium and Luxemburg banks predominantly based on private banking that maintains banking secrecy and investment management activities.

FIGURE 4: Indices of Intellectual Capital (Source: Chen et al, 2004)

\begin{tabular}{|c|c|c|}
\hline IC Component & Characteristics & Indicators \\
\hline \multirow{13}{*}{ Human Capital } & \multirow{6}{*}{ Employees' competence } & Strategic leadership of the management \\
\hline & & Efficiency of employee training \\
\hline & & Qualities of the employees \\
\hline & & Learning ability of the employees \\
\hline & & $\begin{array}{l}\text { The employees' ability to participate in } \\
\text { policy making }\end{array}$ \\
\hline & & $\begin{array}{l}\text { Training of key technical and managerial } \\
\text { employees }\end{array}$ \\
\hline & \multirow{4}{*}{ Employees' creativity } & Employee's creative ability \\
\hline & & Income on employees' original ideas \\
\hline & & Employees' attitude \\
\hline & & Identification with corporate values \\
\hline & \multirow{4}{*}{ Employees' attitude } & Identification with corporate values \\
\hline & & Satisfaction degree \\
\hline & & Employees' turnover rate \\
\hline \multirow{9}{*}{ Structural Capital } & & Employees' average serviceable life \\
\hline & \multirow[b]{2}{*}{ Corporate culture } & Construction of company culture \\
\hline & & $\begin{array}{l}\text { Employee's identification within } \\
\text { company }\end{array}$ \\
\hline & \multirow{3}{*}{ Operation process } & Business process period \\
\hline & & Product quality level \\
\hline & & Corporate operating efficiency \\
\hline & \multirow[t]{2}{*}{ Organizational structure } & $\begin{array}{l}\text { Clarification of relationship among } \\
\text { authority, responsibility and benefit }\end{array}$ \\
\hline & & Validity of enterprise controlling system \\
\hline & Organizational learning & $\begin{array}{l}\text { Construction and utilization of inner } \\
\text { information net Construction and } \\
\text { utilization of company repository }\end{array}$ \\
\hline
\end{tabular}




\begin{tabular}{l|ll}
\hline IC Component & \multicolumn{1}{c}{ Characteristics } & \multicolumn{1}{c}{ Indicators } \\
\hline \multirow{2}{*}{ Information system } & $\begin{array}{l}\text { Mutual support and cooperation between } \\
\text { employees } \\
\text { Availability of enterprise information } \\
\text { Sharic marketing capability }\end{array}$ & Customer service capability \\
& & Identifying ability of customer's needs \\
& & Market share \\
& & Market potential \\
& & Unit sales to customer \\
Relational Capital & & Brand and trademark reputation \\
& & Construction of sales channel \\
& & Customer satisfaction \\
& & Customer complaint \\
& & Customer outcome \\
& & Investment on customer relationship \\
& &
\end{tabular}

IV (A) HUMAN CAPITAL AND ORGANIZATIONAL PERFORMANCE

Recognized as the central component of IC, Bontis (1998) refers to human capital as "the source of innovation and strategic renewal" that includes all intangibles i.e. the knowledge, skills, experiences and abilities of the members of the firm (Edvinsson and Malone, 1997; Roslender and Fincham, 2004). Extremely reliant on intellectual excellence of managers, knowledge retention has been a concern for bank management (Stovel and Bontis, 2002; Bontis and Fitz-Enz, 2002). Arguing that knowledge required for banking operations is more complex than in most industries and can be lost through seasoned bankers leaving the bank. Shih et al. (2010) highlighted the need for knowledge retention as a core driver of competitiveness, while Namasivayam and Denizci (2006) recognized that customers' perceived value is subject to emotional intelligence, creativity and product knowledge for frontline bankers. Employee satisfaction is closely associated with commitment to the organization (Brooke et al., 1988; Cramer, 1996), employee morale and motivation (Bontis and Fitz-Enz, 2002) and retention (Mowday et al., 1982) resulting in better customer service and sustainable financial results. Bontis (1998); Tseng and Goo (2005); Wang and Chang (2005); Cohen and Kaimenakis (2007); Cabrita and Bontis, (2008); Jardon and Martos (2009); Sharabati et al. (2010) and Mention and Bontis (2013) evidenced the dominant function of $\mathrm{HC}$ on firm's performance either directly or indirectly through RC and SC. 


\section{IV (B) Structural Capital and Organizational Performance}

Cabrita and Bontis (2008) defined structural capital as the organization's capabilities to meet its internal and external challenges including infrastructures, information systems, routines, procedures and organizational culture. SC is primarily the infrastructure that persuades the $\mathrm{HC}$ to create and leverage its knowledge (Edvinsson and Sullivan, 1996). Bank managers are increasingly shifting their major focus on assets productivity, capital efficiency and revenue growth with cost reduction and innovation with the help of ICT (Cabrita and Bontis, 2008) by value addition to clientele through online, real-time access to banks' operation (e-banking, mobile banking) (Gago and Rubalcaba (2007). While SC does not bank's performance on its own (Stewart, 1997), they play a critical role in leveraging IC into increasing the value of an organization coupled with work processes and knowledge development (Soh and Markus, 1995).

\section{IV (C) Relational Capital and Organizational Performance}

Relational Capital refers to the ability of an organization to interact with a wide range of external stakeholders (such as customers, suppliers, competitors, and industry associations) as well as the knowledge embedded in these relationships (Bontis, 1998; Edvinsson and Malone, 1997; Sveiby, 1997). Bontis (2013) found that loyalty, reputation and professional associations determine success in banking industry, acting as information provider, catalyst for networking activities and lobbyist toward supranational entities (Kotler and Keller, 2006; Berry and Parasuraman, 1991; Chaudhuri and Holbrook, 2001). Employees' satisfaction, motivation and commitment foster customer satisfaction, loyalty and retention, leading to higher productivity (Kaplan and Norton, 1996, 2004).

\section{V.INTREGATION OF BALANCED SCOPRECARD AND INTELLECTUAL CAPITALFOR ORGANIZATIONAL PERFORMANCE:}

Arora (2002) discussed about the implementation of intellectual capital accumulation though effective use of BSC. BSC has emerged as a powerful strategic management tool (Bontis et al., 1999; Johanson et al., 2001a, b), and is complementary to IC (Bukh et al., 2002). Kaplan and Norton (2004a) emphasized on how to align intangible assets i.e. IC to an enterprise's strategy by creating customized strategy maps that allow organizations to incorporate investments in people, technology, and organizational capital. They also indicated that the measurement and management of IC contributes to the transformation of non-financial performances into financial performances of 
organizations through BSC (Kaplan and Norton, 2004b). However, they only focused on the learning and growth perspective of BSC. Wu (2002) argued that the distinctive structure of BSC guides both the formation and reinforced management of IC.

According to his findings, strategic objectives under BSC's learning-andgrowth perspective are antecedent of the innovation capital and human capital in IC; strategic objectives under BSC's internal-business-process perspective, the process capital; strategic objectives under BSC's customer perspective, the relationship capital. Several studies have suggested that BSC can be used to measure and manage IC (Businessline, 2002; Andriessen 2004). Skandia, one of Sweden's leading global financial companies, developed a systematic way of visualizing and measuring IC through BSC. The Skandia Navigator has been followed by several other companies, including Dow-Chemicals, CIBC, HewlettPackard and Canon in a customized form. Businessline (2002) believed that Skandia links IC indicators with its financial results building on BSC model. Bontis et al. (1999), Petty and Guthrie (2000) and Mouritsen et al (2005) indicated that both BSC and IC indicators are interesting and relevant; treating strategy as an explicit part of a performance management system. Their study, however, advocated that the ideas of IC and BSC differ in terms of their association with firm's strategy, organization and management that create fundamentally diverse management decision-making.

Integration of BSC and IC management have been a focal point in Taiwanese research field. Yu-Shin Tseng (2006), Chung-Ming Chang (2012), Mei-Fen Wu (2012), and Yung-Chieh Chien (2012), among several others, observed the effects of BSC implementation on the IC accumulation of Taiwanese Companies with results showing that: IC accumulation has a full mediation effect on BSC implementation and organizational performance. Chen (2006) studied connections between IC and BSC using the typical correlation analysis and concluded that the higher consistency in effective IC applications, the better the company's operating performance. Chen (2011), through case study, and Dang (2011), through a Path Analysis Model, demonstrated that IC exerts a positive influence on a company's financial performance. Yu (2003), through a regression analysis of IC and non-financial BSC perspectives in Taiwan-based banks, concluded that a good-fitting model can be constructed incorporating the components of IC with non-financial BSC indicators, and that non-financial indicators have explanatory power regarding the financial indicators. 


\section{CONCLUSION AND DIRECTIONS FOR FUTURE RESEARCH}

Business models, in this knowledge intensive era, are exposed to conditions in which intangibles have more value creation capabilities than tangibles (Janosevic, 2009). Reviewing the literature, the following framework is proposed for integration of BSC and IC accumulation for banking sector performance evaluation for future research:

FIGURE 5: Performance Measurement Framework for Banks

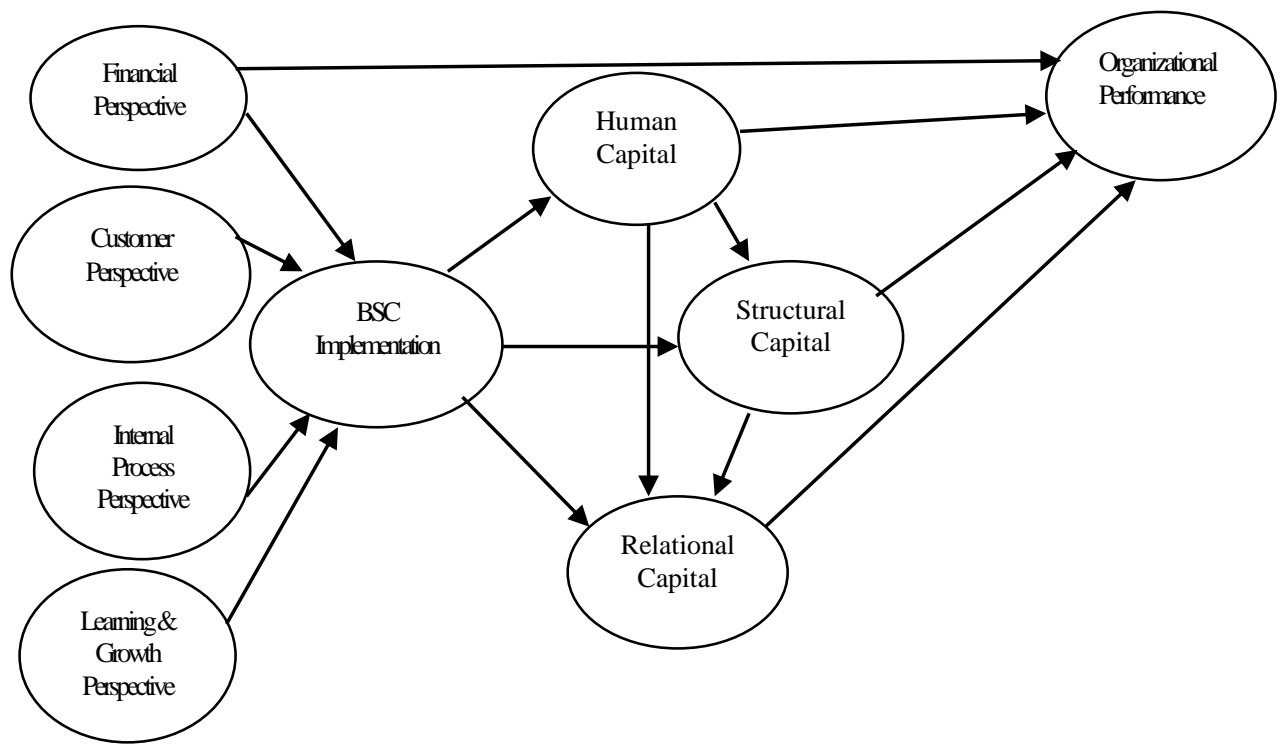

Further study is required to investigate the relationship between IC components in the context of Bangladeshi banks, as academic literature shows sharp deviation in different countries like Portugal, Serbia and Belgium depending on the nature of business. Interesting relationships may also be detected by examining various banking contexts like nationalized, private commercial, foreign commercial and Islamic banks, since Chaminade and Johanson (2003) believed cultural diversity to have a major role to play on intellectual capital enhancement (Bontis, 2004). Different statistical measurement method can be applied to test the same model principles by VAIC (Pulic, 2005), Structural Equation Modeling (Cabrita and Bontis, 2008 and Mention and Bontis, 2013) or ICBS methodology (Viedma, 2002). Finally, future research should also develop objective Key Performance Indicators (KPIs) in terms of BSC and IC for banks. 


\section{REFERENCES}

Abdulsalam, F., Al Qaheri, H., and Al Khayyat, R. (2011). "The Intellectual Capital Performance of Kuwaiti Banks: An Application of VAIC Model", iBusiness, Vol 3, pp. 88-96.

Allee, V. (1999). "The art and practice of being a revolutionary", Journal of Knowledge Management, Vol.3, No.2, pp.121-131.

Andriessen, D. (2004). "Intellectual capital valuation and measurement: classifying the state-of-the-art”, Journal of Intellectual Capital, Vol. 5 No. 2, pp. 230-42.

Arora, R. (2002). "Implementing Knowledge Management: a balanced score card approach", Journal of Knowledge Management, Vol. 6, No. 3, pp. 240-249.

Bontis, Nick (1998). "Managing Organizational Knowledge by Diagnosing Intellectual Capital: Framing and advancing the state of the field", Journal of Technology Management, Vol. 18

Bontis, N, Janosevic, S and Dzenopoljac, V, (2013). "IC and Corporate Performance in Serbian Banks", Actual Problem of Economics, Vol 4 pp.142

Bukh, P.N, Johansen, M.R. and Mouristen, J. (2002). "Multiple Integrated Performance Management Systems: IC and BSC in a Software Company", Singapore Management Review, Vol.24, No.3, pp.21-33.

Businessline (2002). "How to manage intellectual capital", February 11.

Cabrita, M. and Bontis, N. (2008). "Intellectual capital and business performance in the Portuguese banking industry", International Journal of Technology Management, Vol. 43 Nos 1-3, pp. 212-237.

Chang, Chung-Ming (2012). "Verification of the Effects of Balance Scorecard Implementation on a Company's Financial Performance: Using Intellectual Capital Accumulation as the Mediator", The Journal of Global Business Management, Volume 8, No. 2, August 2012 pp.28.

Chen, M.C. (2004), "Intellectual capital and competitive advantages: the case of TTY", Journal of Business Chemistry, Vol. 1 No. 1, pp. 14-20

Chien, Yung-Chieh (2012). "The Influences of Balanced Scorecard upon Intellectual Capital Accumulation Implemented by Listed LED Companies in Taiwan: A moderator of organizational commitment" The Journal of International Management Studies, Volume 7, No. 2, October, 2012, pp 40.

Dave, Sagar\& Dave, Swati (2012). "Applying BSC in Indian Banking Sector: A Empirical Study of the State Bank of India", Pacific Business Review International, Vol 5Issue 6,pg 108.

Edvinsson L. (1997). Developing intellectual capital at Skandia. Long Range Planning 30(3): 366-373. 
Edvinsson L, Malone M. (1997). "Intellectual Capital: Realizing Your Company's True Value by Funding Its Hidden Brainpower." Harper Business: New York, NY.

Garrison, Ray H., Noreen, Eric W, and Brewer, Peter C. (2012). Managerial Accounting. 13th ed. New Delhi: Tata McGraw-Hill Education Private Limited, 2012.

Janošević, S. (2009). The impact of intangible assets on the company strategy, chapter monograph: Developing Competitive Advantage in Serbia in the European Integration (editor: LJ. Stanković), book, the Faculty of Economics, 2009, pg. 43-67.

Johnson, W. (1999). "An integrative taxonomy of intellectual capital: Measuring the stock and flow of intellectual capital components in the firm", Int. J. Technology Management, Vol. 18, Nos. 5/6/7/8, 1999.

Kamath, G. B. (2007). "The intellectual capital performance of the Indian banking sector". Journal of Intellectual Capital, Vol. 8(1): pg 96-123.

Kaplan, Robert S. and Norton, David P. (1996). "Using the balanced scorecard as a strategic management system”, Harvard Business Review, Vol. 74 No. 1, pp. 75-86.

Kaplan R, Norton D. (2004). "Strategy Maps: Converting Intangible Assets into Tangible Outcomes", Harvard Business School Press: Boston, Massachusetts.

Larsen, H.T, Buku, PD. and Mouritsen, T. (1999). "Intellectual capital statements and Knowledge Management measuring, reporting and analyzing", Australian Review.

Leana, C. R. and Van Buren, H. J. (1999). "Organizational social capital and employment practices", Academy of Management Review, 24(3), 538-555.

Mavridis GD. (2004). The intellectual capital performance of the Japanese banking sector. Journal of Intellectual Capital, 5(1): 92-115.

Mention, Anne-Laure and Bontis, Nick (2013). "Intellectual capital and performance within the banking sector of Luxembourg and Belgium", Journal of Intellectual Capital, Vol. 14 No. 2, pp. 286-309.

Mouritsen, J., Thorsgaard, L., \& Bukh, P. N. (2005). Dealing with the knowledge economy: Intellectual capital versus balanced scorecard. Journal of Intellectual Capital, 6 (1), 8-27.

Reed, K.K., Lubatkin, M. and Srinivasan, N. (2006). "Proposing and testing an intellectual capital based view of the firm", Journal of Management Studies, Vol. 43 No. 4, pp. 867-893.

Roos, J; Roos, G.; Dragonetti, N.; Edvinsson, L. (1997). Intellectual capital: Navigating the new business landscape. Macmillan Press Ltd, London.

Stewart, TA. (1997). Intellectual Capital: The New Wealth of Organizations. Nicholas Brealey Publishing, London. 
Sullivan, PH. (2000). "Value-Driven Intellectual Capital: How to Convert Intangible Corporate Assets into Market Value". John Wiley \& Sons: New York, NY.

Sveiby, Karl- Erik (1998). "Intellectual capital: Thinking ahead.” Australian CPA, Vol. 68 No. 5 , pp. $18-22$.

Wu, Anne (2005). "The integration between Balanced Scorecard and intellectual capital", Journal of Intellectual Capital, Vol. 6 No. 2, 2005, pp. 267-284.

Wu, Hung-Yi; Tzeng, Gwo-Hshiung; Chen, Yi-Hsuan (2009). "A fuzzy MCDM approach for evaluating banking performance based on Balanced Scorecard", Expert Systems with Applications 36 (2009) 10135-1014, Elsevier Ltd.

Wu, Mei-Fen (2012). "The Effects of Balanced Scorecard Implementation on the Intellectual Capital Accumulation of Taiwan-listed IT Companies: Using Corporate Innovation Activities as the Moderator", The Journal of Global Business Management, Vol 8, No. 2, August 2012 pp. 82.

Zimmerman, J., (2000). Accounting for Decision Making and Control. Irwin McGrawHill, Boston. 